\title{
SDS-PAGE and immunological analysis of different axenic Blastocystis hominis strains
}

\author{
K. G. KUKOSCHKE and H. E. MÜLLER*
}

Staatliches Medizinaluntersuchungsamt, Hallestraße 1, D-3300 Braunschweig, Germany

\begin{abstract}
Summary. Consistent major differences were detected by SDS-PAGE, Western blotting and Ouchterlony immunodiffusion in four axenic and microscopically indistinguishable strains of the anaerobic human parasite Blastocystis hominis from different sources. It is concluded that at least two variants with different polypeptide patterns and antigens exist and the biological significance of these findings is discussed.
\end{abstract}

\section{Introduction}

There is no general agreement on the taxonomic position and the pathogenic potential of the anaerobic, eukaryotic parasite Blastocystis hominis. ${ }^{1-3}$ Early studies reported its association with diarrhoea, ${ }^{4-6}$ but this is still the subject of debate. ${ }^{2,7-9}$ Since Zierdt et al. studied the organism and assigned it to the protozoa, ${ }^{10}$ several reports, with increasing frequency, have been published proposing that $B$. hominis is a cause of diarrhoea and abdominal discomfort in $\operatorname{man}^{11-19}$ especially in immunocompromised patients. ${ }^{20,21}$ However, the organism is also found in healthy people. ${ }^{22,23}$

After the application of axenic cultivation methods by Zierdt and Williams, ${ }^{24} B$. hominis has been described almost completely in morphological terms by several groups of workers. ${ }^{3,19-26}$ Because the development of a direct immunofluorescence assay provided evidence for the existence of serologically different strains (unpublished observations), the present study was performed to analyse polypeptides and antigens of axenic strains of $B$. hominis from different sources with corresponding rabbit antisera.

\section{Materials and methods}

\section{B. hominis strains}

Strains 1,2 and 4 were faecal isolates from three patients living in the area of Braunschweig, Germany, and suffering from diarrhoea; strain 5 was from a healthy person with no enteritic symptoms. Despite routine testing for enteropathogens such as Campylobacter, Salmonella and Shigella spp., Staphylococcus aureus, Yersinia enterocolitica, protozoa, rotavirus and enteropathogenic Escherichia coli, as well as for

Received 5 June 1990; revised version accepted 30 Nov. 1990. * Correspondence should be sent to Professor H. E. Müller. organisms of questionable pathogenic significance such as Candida albicans and Proteus mirabilis, no other potentially pathogenic micro-organisms were detected in any of the faecal specimens.

\section{Culture for $B$. hominis}

Cultures were incubated on the day that the faecal samples were received; $100 \mu 1$ of liquid stool from diarrhoeic samples and $100 \mathrm{mg}$ of the normal sample from the healthy person were inoculated into culture medium which had been kept anaerobic in the $\mathrm{O}_{2}$ free atmosphere of a Gas-Pak jar system (BBL Microbiology Systems) at $36 \pm 1{ }^{\circ} \mathrm{C}$ for one week before use. ${ }^{24}$ The cultures were incubated anaerobically for 5 days. $B$. hominis grew as a sediment at the base of the slant of culture medium. For subcultures, half of the cellular sediment after 5 days was transferred to new pre-incubated medium.

\section{Culture medium}

Locke's solution, composed of $\mathrm{NaCl} 8.0 \mathrm{~g}, \mathrm{CaCl}_{2}$ $0.2 \mathrm{~g}, \mathrm{KCl} 0.2 \mathrm{~g}, \mathrm{MgCl}_{2} 0.01 \mathrm{~g}, \mathrm{Na}_{2} \mathrm{HPO}_{4} \cdot 12 \mathrm{H}_{2} \mathrm{O}$ $2.0 \mathrm{~g}, \mathrm{NaHCO}_{3} 0.4 \mathrm{~g}, \mathrm{KH}_{2} \mathrm{PO}_{4} 0.3 \mathrm{~g}$ in $1 \mathrm{~L}$, was autoclaved at $121^{\circ} \mathrm{C}$ for $15 \mathrm{~min}$. After cooling to room temperature it was filtered to remove the precipitate. One part whole beaten egg was added to 3.6 parts (v/v) of Locke's solution; the mixture was filtered through gauze and $2.5-\mathrm{ml}$ portions were pipetted into $12 \times 35 \mathrm{~mm}$ tubes and inspissated at a $30^{\circ}$ slant for $3 \mathrm{~h}$ at $80^{\circ} \mathrm{C}$. After cooling, slopes were overlayed with $6 \mathrm{ml}$ of Locke's solution containing sterile rabbit serum $25 \% \mathrm{v} / \mathrm{v}$ and covered with $3.5 \mathrm{ml}$ of mineral oil (Merck 7174). $^{3}$

\section{Microscopic examination}

Before transfer, at the end of a subculture period, a 20- $\mu$ sample of culture sediment was examined with a 
Zeiss Axioskope with $100 \times / 1 \cdot 30$ Plan-Neofluar oil immersion objectives. The size, shape and number of $B$. hominis cells per examination field were recorded routinely for all strains according to the classification scheme described by Zierdt. ${ }^{27}$ In all strains, predominantly vacuolated cells of $10-20 \mu$ m diameter, dividing by binary fission, were present in the axenic cultures; granular cells or amoeboid forms were very rare. One third to one half of the total number of cells usually contained intracellular inclusions.

\section{Axenisation}

Subcultures were made by transferring half of the cellular sediment in $1.5 \mathrm{ml}$ of supernate to a new preincubated tube. Subcultures were incubated for 5 days before the new transfer. Extracellular bacteria were eliminated in the presence of ampicillin $4 \mathrm{~g} / \mathrm{L}$, streptomycin $1 \mathrm{~g} / \mathrm{L}$ and colistin $1.5-4.0 \mathrm{mg} / \mathrm{L}$ after $8-10$ transfers. ${ }^{24}$ Cultures that appeared to contain no extracellular bacteria after microscopic examination were checked for microbial growth by subculture on sheep-blood agar plates incubated at $36^{\circ} \mathrm{C}$ for 3 days in aerobic and anaerobic conditions. Those cultures without microbial growth in these conditions were designated as axenic. To minimise the production of antibodies directed against components of the culture medium, rabbit serum $25 \% \mathrm{v} / \mathrm{v}$ was used for cultivation. The axenic cultures were grown for 3-6 months before immunisation.

\section{Preparation of antisera}

Antigenic materials were handled under sterile conditions. The sediments of four parallel axenic cultures of strains 1 and 2 were pooled and pelleted by centrifugation (Hettich-Mikroliter centrifuge, type 2025) for $5 \mathrm{~min}$. The supernates were discarded, and the pellets were washed twice with $0.5 \mathrm{ml}$ of FTAbuffer ( $\mathrm{pH} 7 \cdot 2$ ) consisting of $10 \mathrm{mM} \mathrm{Na}_{2} \mathrm{HPO}_{4} \cdot 2 \mathrm{H}_{2} \mathrm{O}$, $1.5 \mathrm{mM} \mathrm{KH}_{2} \mathrm{PO}_{4}$ and $120 \mathrm{mM} \mathrm{NaCl}$. Then the cells from each strain were suspended in $2.0 \mathrm{ml}$ of FTAbuffer. The suspensions were checked again for microbial growth by culture of a sample on sheepblood agar. No microbial contamination was detected in any case. The cells were killed by heat treatment $\left(65^{\circ} \mathrm{C}, 30 \mathrm{~min}\right)$ and the stock suspensions were divided into $0 \cdot 1-\mathrm{ml}$ volumes and kept frozen at $-20^{\circ} \mathrm{C}$. For immunisation, $0 \cdot 1 \mathrm{ml}$ of a stock suspension was diluted with $0.9 \mathrm{ml}$ of FTA to give a turbidity reading of McFarland standard No. 2. These suspensions were each mixed with $1.5 \mathrm{ml}$ of incomplete Freund's adjuvant (Sigma F5506) as a water-in-oil-emulsion and $1.5 \mathrm{ml}$ of this emulsion was injected into skeletal muscles of 4-month-old male rabbits at weekly intervals. The animals were bled after 9 weeks; the sera were collected and kept frozen at $-20^{\circ} \mathrm{C}$.
Sodium dodecyl sulphate-polyacrylamide gel electrophoresis ( $S D S-P A G E$ )

Axenic culture sediments were collected with a pasteur pipette, pelleted by centrifugation and washed twice in FTA. Proteins of $B$. hominis were extracted by boiling one washed pellet in $40 \mu \mathrm{l}$ of the sample buffer (glycerol $10 \% \mathrm{v} / \mathrm{v}$, SDS $1 \% \mathrm{w} / \mathrm{v}, 0.001 \mathrm{~m}$ edetic acid, $\beta$-mercaptoethanol $2 \% \mathrm{v} / \mathrm{v}$, Bromophenol blue $0.05 \% \mathrm{w} / \mathrm{v}$ in double-distilled water) for $10 \mathrm{~min}$. After centrifugation and cooling, another $2 \% \mathrm{v} / \mathrm{v}$ of $\beta$ mercaptoethanol were added to prevent rearrangement of disulphide bridges. A 40- $\mu$ l sample containing c. $20 \mu \mathrm{g}$ of protein was electrophoresed in polyacrylamide $8 \%$ or $10 \%$ gels (stacking gels $3.5 \%$ ) according to the method of Laemmli. ${ }^{28}$ Gels were $1.5 \mathrm{~mm}$ thick and the apparatus GE-2/4 (Pharmacia, Uppsala, Sweden) was equipped with gel casettes $18 \times 14 \mathrm{~cm}$ and a power supply ECPS $3000 / 150$. Gels were run, with cooling, for $1.5 \mathrm{~h}$ at $80 \mathrm{~V}$ and $15 \mathrm{~mA}$ (stacking gels) and for $4 \mathrm{~h}$ at $300 \mathrm{~V}$ and $10 \mathrm{~mA}$ (separation gels). They were calibrated with Sigma MW-SDS-70-L and MW-SDS-200 mol.-wt marker kits. Gels were stained by gentle agitation at room temperature overnight in a mixture of methanol $150 \mathrm{ml}, 100 \% \mathrm{w} / \mathrm{v}$ trichloroacetic acid $100 \mathrm{ml}$, Coomassie Brilliant Blue R $2500.6 \mathrm{~g}$ in $560 \mathrm{ml}$ of double-distilled water. Gels were destained in a 50/50/7 v/v/v mixture of water, methanol and acetic acid for $6 \mathrm{~h}$, changing the solution five times.

\section{Western blots}

Proteins were transferred from the gels to a PVDF membrane (Immobilon $0.22 \mu \mathrm{m}$; Millipore IPVH 000 10) by established methods ${ }^{29}$ with a Pharmacia GD-4 II device. The transfer buffer $(\times 5)$ consisted of $0 \cdot 125 \mathrm{M}$ tris(hydroxymethyl)-aminomethane (Merck 8382), $0.96 \mathrm{M}$ glycine (Merck 4201) and $0.5 \mathrm{M} \mathrm{NaCl}, \mathrm{pH} 8.3$; $200 \mathrm{ml}$ of transfer buffer concentrate, $100 \mathrm{ml}$ of methanol and $700 \mathrm{ml}$ of double-distilled water were mixed prior to use. After protein transfer, the remaining gel was stained with Coomassie Blue as described above. The blots were washed for $5 \mathrm{~min}$ in transfer buffer and then incubated for $1 \mathrm{~h}$ in blocking solution (PBS with $10 \mathrm{~mm}$ potassium phosphate, $130 \mathrm{~mm} \mathrm{NaCl}, \mathrm{pH} \mathrm{7.4,+Tween} 200.05 \% \mathrm{v} / \mathrm{v}$ and defatted milk powder $5 \% \mathrm{w} / \mathrm{v}$ ). Then whole rabbit antiserum at final dilutions of 1 in 100 and 1 in 66 was added, and the mixture was incubated overnight at room temperature with gentle agitation. The next morning, the blots were washed four times, for $5 \mathrm{~min}$ each, in PBS-buffer and then incubated for $1 \mathrm{~h}$ with peroxidase-conjugated second antibody (anti-rabbit IgG from goat, Sigma 0545) at a final dilution of 1 in 1000 in blocking solution. The immunoblots were then washed four times, for $5 \mathrm{~min}$ each, with PBS-buffer and developed in a solution of 4-chloro-1-naphthol (Sigma C 8890) $0.5 \mathrm{mg} / \mathrm{ml}$ in a mixture of PBS $80 \mathrm{ml}$ and mercaptoethanol $(\mathrm{MeOH}) 16 \mathrm{ml}$ after addition of 
$0 \cdot 1 \mathrm{ml}$ of $\mathrm{H}_{2} \mathrm{O}_{2}$. After development, the blots were washed extensively with PBS-buffer and photographed. Photographs were taken with an Olympus OM. 2 fitted with a macro-objective OM $50 \mathrm{~mm}$ and Agfa PAN 25 film.

\section{Immunodiffusion experiments}

These were done by the method of Ouchterlony ${ }^{30}$ with antisera directed against strains 1 and 2 . The axenic cellular material $(100 \mu \mathrm{l})$ from the Blastocystis strains was suspended in $300 \mu \mathrm{l}$ of FTA and sonicated for $40 \mathrm{~s}$ ("high 278") with a Labsonic 2000 sonicator (B. Braun, Melsungen, Germany). Measurements of $\mathrm{OD}_{280}$ indicated, for all sonicated strains, protein concentrations in the range $1.0-1.2 \mathrm{mg} / \mathrm{ml}$. The diffusion holes were filled with $50-\mu \mathrm{l}$ portions of the sonicated material. Diffusion was for 12 days with $100 \mu \mathrm{l}$ of the undiluted rabbit antisera 1 and 2 at $4^{\circ} \mathrm{C}$.

\section{Results}

SDS-PAGE of axenic culture sediments from strains 1 and 2 indicated that both polypeptide patterns were related, but not completely identical (fig. 1). Based on these apparently different patterns, and on evidence of serologically different strains provided by the direct immunofluorescence assay (unpublished observation), a more detailed immunological investigation was performed with rabbit antisera raised against axenic cell suspensions from strains 1 and 2 .

Western blot analysis revealed that the antiserum raised against axenic cells from strain 1 reacted with protein components from strain 1 at working dilutions of 1 in 100 , but only a very weak cross-reaction, yielding no discrete bands, was observed with protein

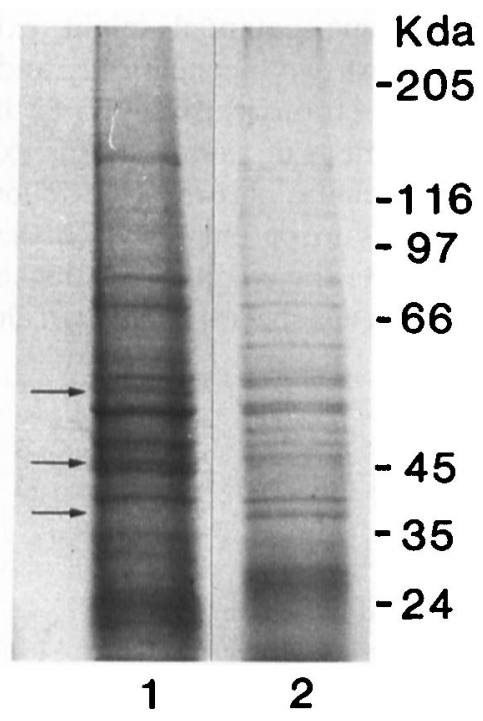

Fig. 1. SDS-PAGE ( $8 \%$ gels) of protein extracts from axenic $B$. hominis strains 1 and 2 under reducing conditions; Coomassie Brilliant Blue staining. Mol.-wt Kda markers: trypsinogen 24, pepsin 35 , ovalbumin 45 , bovine serum albumin 66 , phosphorylase b 97, $\beta$-galactosidase 116 , myosin $\mathrm{H}$-chain 205 . The arrows indicate significant differences between strains. extracts derived from strain 2 (fig. $2 \mathrm{~A}$ ), indicating that strains 1 and 2 were immunologically different. In conformity experiments, a protein extract from strain 2 was found to react with antiserum obtained by immunisation with a cell suspension from strain 2 at a working dilution of 1 in 66 ; again, only a very weak cross-reaction was observed with a protein extract from strain 1 (fig. 2B).

Further immunological evidence for the existence of two different strains was provided by the results of Ouchterlony immunodiffusion. A precipitin band was observed with sonicated cells from strain 1 and antiserum raised against strain 1; no precipitin band was detected with sonicated material from strain 2 . Immunodiffusion experiments with antiserum directed against strain 2 yielded a precipitin band with cells from strain 2 but not with material from strain 1 (fig. 3).

Analysis of two further axenic $B$. hominis strains (4 and 5) indicated that the protein pattern of strain 1 corresponded to that of strain 5 , and the pattern of strain 2 corresponded to that of strain 4 . Strain 4 gave the same immunological reactions as the cellular material from strain 2 (by both Western blot and immunodiffusion techniques), but not the same as that from strain 1 . Contrary to that finding, strain 5 reacted with antiserum raised against strain 1 in the Western blot and immunodiffusion assay, but did not react with material from strain 2 (data not shown).

Reactivity against homologous material in both Western blot and immunodiffusion systems was lost after absorption of the antisera with the appropriate antigenic strains. The results of the immunological analysis are summarised in the table.

\section{Discussion}

Four axenised strains of $B$. hominis from independent sources were separated into two groups by three methods-SDS-PAGE, Western blotting and immunodiffusion. Strains 1 and 5 , in one case, and strains 2 and 4 in the other, showed indistinguishable polypeptide patterns and immunological reactions. The detection of numerous bands, as was found in the case of corresponding sera and antigens by Western blots, and almost no cross-reactions except for weak, undefined smears (probably from lipid- or glycosylcomponents) with heterologous sera treated by the same extraction procedure, confirms that there is no close immunological relationship between the two pairs of strains. The latter findings match completely the results of the immunodiffusion experiments. All results together lead to the conclusion that the specific name Blastocystis hominis describes at least two different variants.

Based on ultrastructural investigations, Dunn et al. ${ }^{1}$ recently described a variation in $B$. hominis stocks from different sources in culture. Taking this into account, our conclusion that $B$. hominis includes at 
A

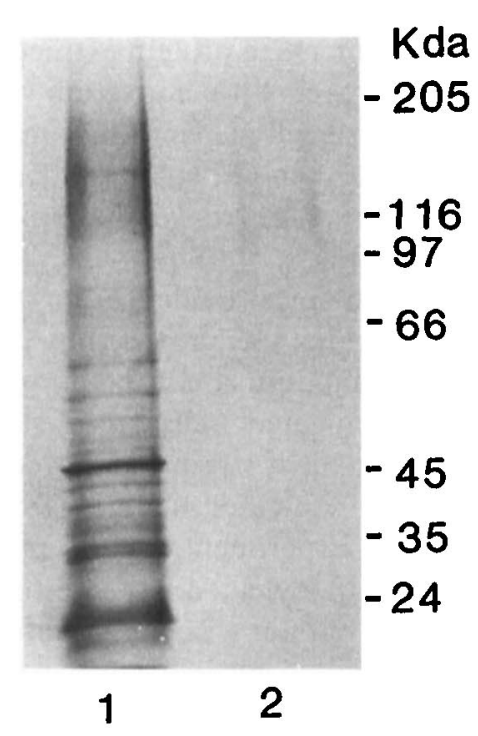

B

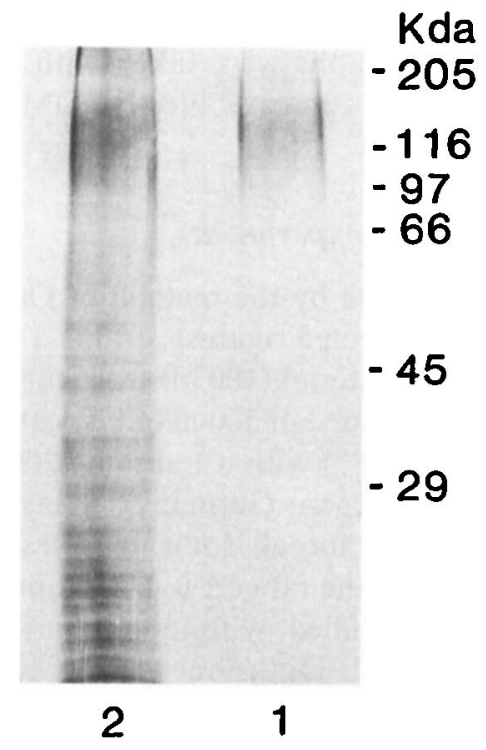

Fig. 2. Western blots after SDS-PAGE under reducing conditions of protein extracts from axenic $B$. hominis strains 1 and 2 with antiserum against strain $1(\mathrm{~A}, 8 \%$ gel) and against strain $2(\mathrm{~B}, 10 \%$ gel). Secondary antibodies were anti-rabbit IgG from goat, HRPO-conjugated. For markers see legend to fig. 1, except for carbonic anhydrase $29 \mathrm{Kda}$. With homologous sera numerous bands are present, whereas with heterologous sera only barely visible cross-reaction occurred.

\section{Antiserum against strain $1 \quad$ Strain 1 against strain 2}

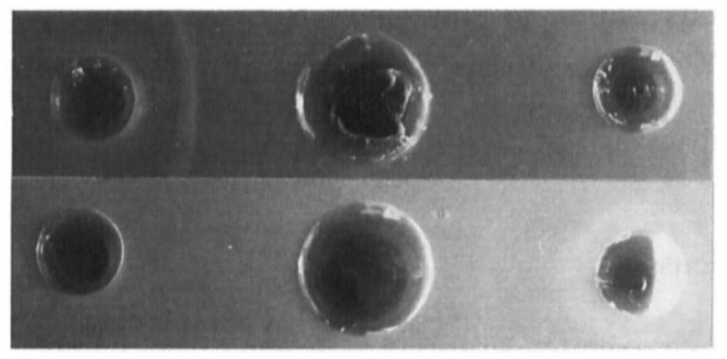

Antiserum against strain $1 \quad$ Strain $2 \quad \begin{gathered}\text { Antiserum strain } 2 \\ \text { against }\end{gathered}$

Fig. 3. Immunodiffusion of sonicated cellular material from strains 1 and 2 with rabbit antisera obtained by immunisation with strain 1 and strain 2. Photographs were taken after incubation for 12 days at $4^{\circ} \mathrm{C}$. least two different variants seems to be reasonable, although the relationships between the ultrastructural variations and the differences in antigen and protein patterns reported in the present study remain to be established.

In a previous study ${ }^{31}$ we reported that the parasites were found more frequently in stool specimens from healthy persons than in those from patients with diarrhoea and this observation was in agreement with the results of other investigators. ${ }^{22}$ Such findings were rationalised by the hypothesis that different types of $B$. hominis exhibiting the same morphology but with a different pathogenic potential might exist. ${ }^{31}$ Our finding that at least two biochemically and immunologically different strains exist supports this theory. However, the number of axenic strains examined is too small for a general classification following such criteria and needs to be enlarged. Further work is needed to elucidate the complex relationships in the hitherto homogeneous species $B$. hominis. Our findings

Table. Immunological reactions of four different axenic strains of $B$. hominis with two rabbit antisera in Western blots and immunodiffusion assays

\begin{tabular}{|c|c|c|c|c|c|}
\hline \multirow{2}{*}{ Method } & \multirow{2}{*}{ Rabbit antiserum } & \multicolumn{4}{|c|}{ Reaction between antiserum and antigens from strains } \\
\hline & & 1 & 2 & 4 & 5 \\
\hline $\begin{array}{l}\text { Western blot } \\
\text { Immunodiffusion }\end{array}$ & Against strain 1 & $\begin{array}{l}\text { Yes } \\
\text { Yes }\end{array}$ & $\begin{array}{c}\text { Very weak } \\
\text { No }\end{array}$ & $\begin{array}{c}\text { Very weak } \\
\text { No }\end{array}$ & $\begin{array}{l}\text { Yes } \\
\text { Yes }\end{array}$ \\
\hline $\begin{array}{l}\text { Western blot } \\
\text { Immunodifussion }\end{array}$ & Against strain 2 & $\left\{\begin{array}{c}\text { Very weak } \\
\text { No }\end{array}\right.$ & $\begin{array}{l}\text { Yes } \\
\text { Yes }\end{array}$ & $\begin{array}{l}\text { Yes } \\
\text { Yes }\end{array}$ & $\begin{array}{c}\text { Very weak } \\
\text { No }\end{array}$ \\
\hline
\end{tabular}


contribute to an improved understanding of $B$. hominis infection and do not support the view that no strains of $B$. hominis play an aetiological role in enteritis.

This work was supported by German Bundesanstalt für Arbeit (ABM-No. 491/86/211). We thank Anita Backenköhler, F. Heimbach and Sabine Müller for excellent technical assistance.

\section{References}

1. Dunn LA, Boreham PFL, Stenzel DJ. Ultrastructural variation of Blastocystis hominis stocks in culture. Intern J Parasitol $1989 ; 19: 43-56$.

2. Miller RA, Minshew BH. Blastocystis hominis: an organism in search of a disease. Rev Infect Dis 1988; 10:930-938.

3. Zierdt CH, Donnolley CT, Muller J, Constantopoulos G. Biochemical and ultrastructural study of Blastocystis hominis. J Clin Microbiol 1988; 26: 965-970.

4. Calderin C. Blastocystis hominis como parasito patogeno del hombre. Revista de Medicina Tropical y Parasitologia Bacteriologia Clinca Y Laboratorio (Habana) 1937; 3: 207213.

5. Sangiorgi G. Sulla patogenicita della Blastocystis hominis. Pathologica 1930; 22: 173-176.

6. Yakimoff WL. Sur la question des Blastocystis. Bull Soc Pathol Exot Filiales 1923; 16: 326-330.

7. Kain KC, Noble MA, Freeman HJ, Barteluk RL. Epidemiology and clinical features associated with Blastocystis hominis infection. Diagn Microbiol Infect Dis 1987; 8: 235-244.

8. Markell EK, Udkow MP. Blastocystis hominis: pathogen or fellow traveler? Am J Trop Med Hyg 1986; 35: 1023-1026.

9. Sheehan DJ, Raucher BG, McKitrick JC. Association of Blastocystis hominis with signs and symptoms of human disease. J Clin Microbiol 1986; 24 : 548-550.

10. Zierdt $\mathbf{C H}$, Rude WS, Bull BS. Protozoan characteristics of Blastocystis hominis. Am J Clin Pathol 1967; 48: 495-501.

11. Gallagher PG, Venglarcik JS. Blastocystis hominis enteritis. Ped Infect Dis 1984; 4: 556-557.

12. Garcia LS, Bruckner DA, Clancy MN. Clinical relevance of Blastocystis hominis. Lancet 1984; 1 : 1233-1234.

13. Müller HE. Blastocystis hominis, ein weithin unbekannter Durchfallerreger. Dtsch Med Wochenschr 1987; 112: 1512 1515.

14. Qadri SMH, Al-Okaili GA, Al-Dayel F. Clinical significance of Blastocystis hominis. J Clin Microbiol 1989; 27 : 24072409.
15. Russo AR, Stone SL, Taplin ME, Snapper HJ, Doern GV. Presumptive evidence for Blastocystis hominis as a cause of colitis. Arch Intern Med 1988; 148 : 1064.

16. Vannatta JB, Adamson D, Mullican K. Blastocystis hominis infection presenting as recurrent diarrhea. Ann Intern Med $1985 ; 102$ : 495-496.

17. Zierdt $\mathrm{CH}$. Blastocystis hominis, an intestinal protozoan parasite of man. Public Health Lab 1978; 36: 147-160.

18. Zierdt CH. Blastocystis hominis, a protozoan parasite and intestinal pathogen of human beings. Clin Microbiol Newslett 1983; 5: 57-59.

19. Zierdt $\mathrm{CH}$, Tan HK. Ultrastructure and light-microscope appearance of Blastocystis hominis in a patient with enteric disease. $Z$ Parasitenk 1976 ; 50: 277-283.

20. Garavelli PL, Orsi P, Scaglione L. Blastocystis hominis during AIDS. Lancet 1984; 1: 1364

21. Llibre JM, Tor J, Manterola JM, Carbonell C, Foz M. Blastocystis hominis chronic diarrhoea in AIDS patients. Lancet 1989; 1 : 221.

22. Conen D, Gerber A, Durbach UC. Prävelenz von Blastocystis hominis bei Asylbewerbern. Dtsch Med Wochenschr 1987; 112: 1477.

23. Doyle PW, Helgason MM, Mathias RG, Proctor EM. Epidemiology and pathogenicity of Blastocystis hominis. J Clin Microbiol 1990; 28: 116-121.

24. Zeirdt CH, Williams RL. Blastocystis hominis: axenic cultivation. Exp Parasitol 1974; 36: 233-243.

25. Matsumotu Y, Yamada M, Yoshida Y. Light-microscopical appearance and ultrastructure of Blastocystis hominis, an intestinal parasite of man. Zentralbl Bakteriol Mikrobial Hyg [A] 1987; 264: 379-385.

26. Silard R, Panaitescu D, Burghelea B. Ultrastructural aspects of Blastocystis hominis. Arch Roum Pathol Exp Microbiol 1983; 42: $233-242$

27. Zeirdt CH. Studies of Blastocystis hominis. J Protozool 1973; 20: 114-121.

28. Laemmli UK. Cleavage of structural proteins during the assembly of the head of bacteriophage T4. Nature 1970; 227: 680-685.

29. Towbin H, Staehelin T, Gordon J. Electrophoretic transfer of proteins from polyacryamide gels to nitrocellulose sheets: procedure and some applications. Proc Natl Acad Sci USA $1979 ; 76: 4350-4354$

30. Ouchterlony Ö. Diffusion-in-gel methods for immunological analysis II. In: Kallos P, Waksman $\mathrm{H}$ (eds) Progress in allergy, vol 6. Basel, Karger. 1962: 30-154.

31. Kukoschke KG, Necker A, Müller HE. Detection of Blastocystis hominis by direct microscopy and culture. Eur J Clin Microbiol Infect Dis 1990; 9: 305-307. 